\title{
Differentiation Inhibitor
}

National Cancer Institute

\section{Source}

National Cancer Institute. Differentiation Inhibitor. NCI Thesaurus. Code C2131.

An agent that inhibits the differentiation or maturation of cells, specifically neoplastic cells. 